\title{
PENGARUH THERAPEUTIC EXERCISE WALKING TERHADAP KUALITAS TIDUR KLIEN DENGAN PENYAKIT PARU OBSTRUKSI KRONIK (PPOK) DI RS TK II PUTRI HIJAU MEDAN
}

\author{
Elis Anggeria ${ }^{1}$; Eriza Dinamika ${ }^{2}$ \\ ${ }^{l}$ Dosen Fakultas Keperawatan dan Kebidanan UNPRI; ${ }^{2}$ Mahasiswa Profesi Ners UNPRI \\ Email: elis.anggeria@gmail.com
}

\begin{abstract}
PPOK becomes the first rank in the group of lung diseases in Indonesia, followed by bronchial asthma, lung cancer and other lung diseases. Therapeutic exercise is an action of running regular walking with hands swayed to the rhythm of the road, this action is excellent for all age levels in order to improve the quality of sleeping. The research aims to find out the effect of therapeutic walking exercise in patients with chronic obstructive pulmonary disease in TK II Putri Hijau Medan Hospital Medan.This research used an experimental desgin by the use of quasi experimental design through pre-test and post-test paired t-test group. The research population were 9 people, and the sampling technique used in this study is saturation sampling technique by taking the entire population as samples. There is the mean difference between pretest and posttest on sleep quality by 0.56, meaning that the average quality of sleep on posttest have a better category than the average quality of sleep on pretest, which means therapeutic exercise of walking affects quality of sleep in patients with chronic obstructive pulmonary disease with p-value of 0,013. There isa a significant effect of therapeutic exercise of walking on sleep quality. Therapeutic exercise of walking is form of therapy that is proven to improve sleep quality, therefore, is expected that patients can perform therapeutic exercise of walking guided by nurses.
\end{abstract}

Keywords: Therapeutic Exercise Walking, Chronic Obstructive Pulmonary Disease, Sleep Quality

\section{PENDAHULUAN}

Penyakit Paru Obstruktif

kronik (PPOK) merupakan masalah kesehatan yang saat ini ada di seluruh dunia. Prevalensi, morbiditas, dan mortalitas PPOK mulai meningkat sehingga mulai membutuhkan perhatian khusus dalam penatalaksanaan dan pencegahan terhadap penurunan progresivitas fungsi paru (Nungtjik, dkk, 2010).

\section{World Health Organization} (WHO) memperkirakan pada tahun 2020 prevalensi PPOK akan terus meningkat dari urutan keenam menjadi peringkat ketiga di dunia sebagai penyebab kematian tersering setelah penyakit kardiovaskular dan kanker. Berdasarkan data American Thoracic Society (ATS) tahun 2011 
terdapat 14 juta penduduk Amerika Serikat terdiagnosa PPOK dan diperkirakan 12 juta lebih penduduk tidak terdiagnosa. Penyakit PPOK berkembang secara lambat dan jarang terjadi pada usia di bawah 40 tahun (American Thoracic Society [ATS], 2011 dalam Oktorina, dkk, 2011). PPOK lebih banyak pada lakilaki $(4,2 \%)$ dibandingkan perempuan $(3,3 \%) \quad$ (Riset Kesehatan Dasar [Riskesdas], 2013).

PPOK menjadi urutan pertama pada kelompok penyakit paru di Indonesia yang memiliki angka kesakitan (35\%), diikuti asma bronkial (33\%), kanker paru (30\%), dan penyakit paru lainnya (2\%) (Shinta, 2008 dalam Oktorina, dkk, 2011). Prevalensi PPOK di Indonesia menempati urutan kedua $(3,7 \%)$ setelah asma (4,5\%). Prevalensi PPOK tertinggi terdapat di Nusa Tenggara Timur $(10,0 \%)$, diikuti Sulawesi Tengah (8,0\%), Sulawesi Barat (6,7\%), Sulawesi Selatan $(6,7 \%)$, Jawa Timur $(3,6 \%)$, dan Sumatera Utara (3,6\%) (Riset Kesehatan Dasar, 2013).

Adapun tujuan dari pemberian therapeutic exercise walking adalah untuk meningkatkan perasaan tentram, rileks, kebugaran tubuh dan membantu istirahat tidur lebih baik. Therapeutic exercise walking dapat meningkatkan sirkulasi darah dan mengoptimalkan suplai oksigen dalam jaringan, sehingga dapat menyebabkan serotonin meningkat.

Serotonin merupakan serum yang dilepaskan oleh sel khusus yang berada di pons dan batang otak tengah yaitu bulbar synchronizing regional (BSR) saat tidur yang dapat memberikan efek tenang. Pada saat tersebut, tingkat fatigue atau kelelahan pasien akan dipulihkan (Pallet et al., 2009 dalam Khomarun, Nugroho, Wahyuni, 2014).

Survey awal yang dilakukan di RS TK II Putri Hijau Medan tahun 2016 didapatkan hasil jumlah penderita PPOK sebanyak 483 orang pada tahun 2012, 376 orang pada tahun 2013, 478 orang pada tahun 2014 dan 447 orang pada tahun 2015.

Klien yang mengalami PPOK melaporkan lebih sering mengalami gangguan tidur dibanding orang sehat. Peneliti tertarik untuk melakukan penelitian dengan judul pengaruh therapeutic exercise 
walking terhadap kualitas tidur klien dengan penyakit paru obstruksi kronik (PPOK) di RS TK II Putri Hijau Medan.

\section{METODOLOGI PENELITIAN}

Penelitian ini menggunakan pre experimental design atau quasi experiment (Notoatmodjo, 2012). Lokasi penelitian di RS TK II Putri Hijau Medan. Penelitian ini dilaksanakan pada bulan Juni 2016.

\section{Populasi dan Sampel}

Populasi dalam penelitian ini adalah pasien yang menderita penyakit paru obstruksi kronik (PPOK) di RS TK II Putri Hijau Medan tahun 2016 sebanyak 9 orang. Teknik sampling jenuh dengan mengambil keseluruhan populasi menjadi sampel (Arikunto, 2014).

\section{Metode Pengumpulan Data}

Metode pengumpulan data dimulai dari mengajukan surat ke permohonan izin pelaksanaan penelitian pada instansi pendidikan program S-1 Keperawatan, kemudian surat izin yang diperoleh diajukan kepada pihak RS TK II Putri Hijau Medan.

\section{Analisis Data}

Pengukuran therapeutic exercise walking terhadap kualitas tidur klien dengan penyakit paru obstruksi kronik (PPOK) dilakuan dua kali, yaitu sebelum pemberian dan setelah pemberian therapeutic exercise walking (post-test).

\section{HASIL DAN PEMBAHASAN}

\section{Hasil Penelitian}

Karakteristik jenis kelamin, usia dan tingkat pendidikan dilihat pada tabel berikut:

Tabel 1 Distribusi Frekuensi dan Persentase Karateristik Responden Berdasarkan Jenis Kelamin, Usia dan Tingkat Pendidikan Responden di RS TK II Putri Hijau Medan (n=9)

\begin{tabular}{lcc}
\hline $\begin{array}{l}\text { Karakteristik Jumlah } \\
\text { Responden }\end{array}$ & $\begin{array}{c}\text { Persentase } \\
(\mathbf{m})\end{array}$ \\
\hline Jenis & & \\
Kelamin & & \\
$\quad$ Laki-laki & 7 & 77,8 \\
Perempuan & 2 & 22,2 \\
\hline$\quad$ Total & 9 & 100 \\
\hline Usia & & \\
$41-50$ & 2 & 22,2 \\
51-60 & 6 & 66,7 \\
$\geq 61$ & 1 & 11,1 \\
\hline$\quad$ Total & 9 & 100 \\
\hline Tingkat & & \\
Pendidikan & & \\
SD & 1 & 11,1 \\
SMP & 1 & 22,2 \\
SMA & 4 & 44,4 \\
Perguruan & 2 & 22,2 \\
Tinggi & & \\
\hline$\quad$ Total & 9 & 100 \\
\hline
\end{tabular}


Berdasarkan tabel diketahui bahwa dari 9 responden mayoritas berjenis kelamin laki-laki sebanyak 7 orang $(77,8 \%)$ dan minoritas perempuan yaitu sebanyak 2 orang $(22,2 \%)$. Berdasarkan usia mayoritas berusia 51-60 tahun sebanyak 6 orang $(66,7 \%)$, minoritas berusia $\geq 61$ tahun sebanyak 1 orang $(11,1 \%)$, dan usia 41-50 tahun sebanyak 2 orang $(22,2 \%)$. Berdasarkan tingkat pendidikan dari 9 responden mayoritas memiliki tingkat pendidikan SMA sebanyak 4 orang (44,4\%), minoritas SD sebanyak 1 orang $(11,1 \%)$, SMP sebanyak 2 orang $(22,2 \%)$ dan sarjana sebanyak 2 orang $(22,2 \%)$.

Tabel 2 Distribusi Frekuensi dan Persentase Karateristik Responden Berdasarkan Pekerjaan, Lama Mengidap PPOK di RS TK II Putri Hijau Medan Tahun (n=9)

\begin{tabular}{lcc}
\hline $\begin{array}{c}\text { Karateristik } \\
\text { Responden }\end{array}$ & $\begin{array}{c}\text { Jumlah } \\
(\mathbf{n})\end{array}$ & $\begin{array}{c}\text { Persentase } \\
(\%)\end{array}$ \\
\hline Pekerjaan & & \\
Wiraswasta & 7 & 77,8 \\
PNS & 2 & 22,2 \\
\hline \multicolumn{1}{c}{ Total } & 9 & 100 \\
\hline Lama & & \\
Mengidap & & \\
PPOK & 1 & 11,1 \\
<3 tahun & 7 & 77,8 \\
3-5 tahun & 1 & 11,1 \\
$>5$ tahun & & \\
\hline \multicolumn{1}{c}{ Total } & 9 & 100 \\
\hline
\end{tabular}

Berdasarkan tabel di atas diketahui bahwa dari 9 responden mayoritas memiliki pekerjaan sebagai wiraswasta sebanyak 7 orang $(77,8 \%)$ dan minoritas Pegawai Negeri Sipil (PNS) sebanyak 2 orang (22,2\%). Berdasarkan lama mengidap PPOK dari 9 responden mayoritas mengidap PPOK selama 3-5 tahun sebanyak 7 orang $(77,8 \%)$, mengidap PPOK selama $<3$ tahun sebanyak 1 orang $(11,1 \%)$ dan $>5$ tahun sebanyak 1 orang $(11,1 \%)$.

Tabel 3 Distribusi Frekuensi dan Persentase Karateristik Responden Berdasarkan Riwayat Merokok dan Lama Merokok di RS TK II Putri Hijau Medan Tahun (n=9)

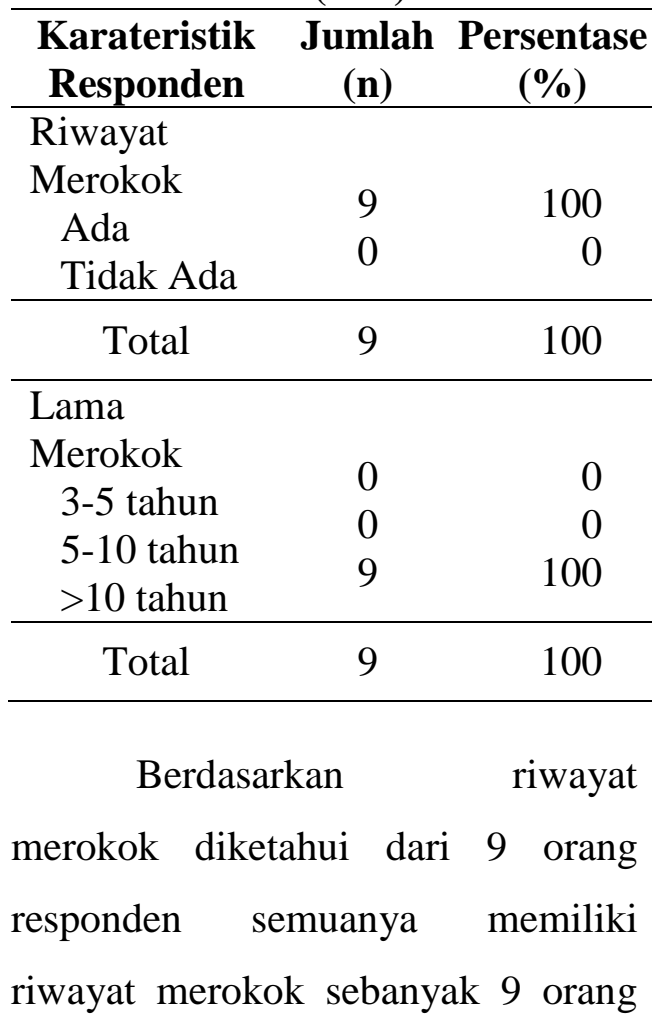


(100\%). Berdasarkan lama merokok, dari 9 orang responden semua responden telah merokok selama $>10$ tahun.

\section{Analisa Univariat}

\section{Kualiatas Tidur}

Hasil distribusi frekuensi dan persentase kualitas tidur pasien PPOK di RS TK II Putri Hijau Medan sebelum dilakukan intervensi (pretest) dan setelah dilakukannya intervensi (posttest) dapat dilihat pada tabel.

Tabel 4 Distribusi Frekuensi dan Persentase Kualitas Tidur Sebelum dan Sesudah Dilakukan Intervensi (pretest posttest) Rsponden di RS TK II Putri Hijau Medan $(\mathbf{n}=9)$

\begin{tabular}{llll}
\hline \multirow{2}{*}{ No Karateristik } & \multicolumn{2}{l}{ Pretest } & \multicolumn{2}{l}{ Posttest } \\
\cline { 2 - 4 } & n $\%$ & N & $\%$ \\
\hline
\end{tabular}

\begin{tabular}{llllll}
\hline 1 & Kualitas & & & & \\
& Tidur & & & & \\
& Baik & 2 & 22,2 & 7 & 77,8 \\
& Buruk & 7 & 77,8 & 2 & 22,2 \\
\hline & Total & 9 & 100 & 9 & 100 \\
\hline
\end{tabular}

\footnotetext{
Berdasarkan tabel diatas diketahui bahwa sebelum dilakukannya intervensi theraupetic exercise walking (pretest) dari 9 orang responden mayoritas memiliki kualitas tidur dengan kategori buruk sebanyak 7 orang $(77,8 \%)$ dan memiliki kualitas tidur dengan
}

kategori baik sebanyak 2 orang $(22,2 \%)$.

Setelah dilakukannya intevensi theraupetic exercise walking (posttest) dari 9 orang responden mayoritas memiliki kualitas tidur dengan kategori baik sebanyak 7 orang $(77,8 \%)$ dan pasien yang memiliki kualitas tidur dengan kategori buruk sebanyak 2 orang $(22,2 \%)$.

\section{Uji Normalitas}

Berdasarkan tabel uji normalitas diketahui bahwa nilai kolmogorov-smirnov pada kualitas tidur (pretest) dan kualitas tidur (posttest) adalah 1,412. Hal ini berarti nilai uji normalitas $>\alpha(0,05)$ yang artinya data diatas berdistribusi normal.

\section{Tabel 5 Uji Normalitas Kolmogorov-Smirnov Data Responden di RS TK II Putri Hijau Medan $(\mathbf{n}=9)$

\begin{tabular}{|c|c|c|}
\hline & $\begin{array}{c}\text { Kualitas } \\
\text { Tidur } \\
\text { (Pretest) }\end{array}$ & $\begin{array}{c}\text { Kualitas } \\
\text { Tidur } \\
\text { (Posttest) }\end{array}$ \\
\hline Kolmogorov- & & \\
\hline Smirnov Z & 1,412 & 1,412 \\
\hline P-value & 0,037 & 0,037 \\
\hline
\end{tabular}

\section{Analisa Bivariat}

Analisis data yang digunakan untuk mengetahui perbedaan nilai 
kualitas tidur sebelum dilakukannya theraupetic exercise walking (pretest) dan sesudah dilakukannya theraupetic exercise walking (posttest) dalam penelitian ini yaitu uji statistik $t$-test.

\section{Tabel 6 Perbedaan Kualitas}

Tidur Sebelum dan Sesudah Dilakukannya Theraupetic Exercise Walking Pada Pasien PPOK di RS TK II Putri Hijau Medan (n=9)

\begin{tabular}{lcccc}
\hline $\begin{array}{l}\text { Kualitas Mean } \\
\text { Tidur }\end{array}$ & $\begin{array}{c}\text { Mean } \\
\text { Difference }\end{array}$ & t & $\begin{array}{c}\text { P- } \\
\text { value }\end{array}$ \\
\hline $\begin{array}{l}\text { Pretest } \\
\text { Posttest }\end{array}$ & 1,78 & 0,56 & 3,162 & 0,013 \\
\hline
\end{tabular}

Berdasarkan tabel 6 diatas diketahui bahwa terdapat perbedaan mean antara kualitas tidur pretest dan posttest sebesar 0,56 , artinya ratarata kualitas tidur posttest mempunyai kategori yang lebih baik dari pada rata-rata kualitas tidur pretest.

Hasil uji t-test menunjukkan nilai signifikansi p-value sebesar 0,013 . Hal ini berarti p-value $<\alpha$ $(0,05)$ sehingga Ho ditolak dan $\mathrm{Ha}$ diterima menunjukkan bahwa terdapat pengaruh therapeutic exercise walking terhadap kualitas tidur klien dengan penyakit paru obstruksi kronik (PPOK) di RS TK II Putri Hijau Medan.

\section{PEMBAHASAN}

\section{Analisa Univariat}

Berdasarkan hasil penelitian sebelumnya diketahui bahwa sebelum dilakukannya theraupetic exercise walking mayoritas pasien PPOK memiliki kualitas tidur dengan kategori buruk yaitu sebanyak 4 orang dan hanya 1 orang pasien PPOK yang memiliki kualitas tidur dengan kategori baik.

Faktor penyakit fisik dalam penelitian ini menjadi salah satu penyebab menurunnya kualtas tidur. Pada penelitian ini mayoritas responden merupakan pasien yang mengidap penyakit PPOK. Penyakit pernafasan seringkali mempengaruhi tidur seperti penyakit emfisema dengan napas pendek dan seringkali tidak dapat tidur tanpa dua atau tiga bantal untuk meninggikan kepala mereka (Potter \& Perry, 2006).

Beberapa responden dalam penelitian ini juga mengatakan bahwa biasanya harus tidur dengan posisi setengah duduk atau memakai bantal yang ditumpuk dibawah kepalanya merasa kesulitan bernapas waktu tidur. 


\section{Analisa Bivariat}

Berdasarkan hasil penelitian sebelumnya, diketahui hasil uji two related sample t-test terdapat perbedaan kualitas tidur pada pasien PPOK sebelum dan sesudah dilakukannya theraupetic exercise walking. Hasil penelitian menunjukkan nilai z-test 3,162 dan nilai $p$-value 0,013 . Hal ini berarti $p$ value $<\alpha(0,05)$ yang artinya Ho ditolak dan $\mathrm{Ha}$ diterima, terbukti bahwa ada pengaruh theraupetic exercise walking dengan kualitas tidur pada pasien PPOK di RS TK II Putri Hijau Medan.

Hasil penelitian ini sejalan dengan penelitian Flowerenty (2015) tentang pengaruh therapeutic exercise walking terhadap kualitas tidur klien dengan penyakit paru obstruksi kronik (PPOK) di Poli Spesialis Paru B RS Paru Jember menunjukkan ada pengaruh yang signifikan therapeutic exercise walking terhadap kualitas tidur. Hasil analisa data menggunakan uji Paired T-test diperoleh nilai $\mathrm{p}$ pada kelompok perlakuan sebesar 0,000 dan 0,262 pada kelompok kontrol. Therapeutic exercise walking merupakan tindakan berjalan biasa dengan mengayunkan tangan sesuai irama jalan, tindakan ini sangat baik dan cocok untuk segala tingkatan umur.

Menurut Khomarun, Nugroho, Wahyuni (2014) tujuan dari pemberian therapeutic exercise walking adalah untuk meningkatkan perasaan tentram, rileks, kebugaran tubuh dan membantu istirahat tidur lebih baik. Therapeutic exercise walking dapat meningkatkan sirkulasi darah dan mengoptimalkan suplai oksigen dalam jaringan.

\section{KESIMPULAN DAN SARAN}

\section{Kesimpulan}

Berdasarkan hasil penelitian dan pembahasan yang telah diuraikan sebelumnya mengenai pengaruh therapeutic exercise walking terhadap kualitas tidur klien dengan penyakit paru obstruksi kronik (PPOK) di RS TK II Putri Hijau Medan dengan jumlah responden 9 orang, maka diperoleh suatu kesimpulan.

Berdasarkan hasil penelitian yang dilakukan di RS TK II Putri Hijau Medan dapat dilihat bahwa sebelum melakukan therapeutic 
exercise walking mayoritas pasien PPOK memiliki kualitas tidur buruk. Setelah

melakukan therapeutic exercise walking diketahui bahwa mayoritas pasien PPOK memiliki kualitas tidur baik. Dapat dilihat peningkatan kualitas tidur sesudah dilakukannya therapeutic exercise walking.

$$
\text { Penelitian terhadap } 9
$$
responden PPOK di RS TK II Putri Hijau Medan menunjukkan terdapat pengaruh yang signifikan therapeutic exercise walking dengan kualitas tidur pada pasien PPOK di RS TK II Putri Hijau Medan dengan uji t-test taraf signifikanasi 5\% didiperoleh nilai $p$-value $=0,013<$ $\alpha(0,05)$.

\section{Saran}

1. Bagi Institusi Pelayanan Rumah Sakit

Bagi institusi pelayanan rumah sakit diharapkan untuk mulai menerapkan therapeutic exercise walking sebagai salah satu alternatif terapi yang telah terbukti efektif dan efisien dalam memperbaiki kualitas tidur khususnya bagi penderita PPOK yang sering mengalami masalah dengan kualitas tidur.
2. Bagi Responden

Therapeutic exercise walking tidak hanya dilakukan di rumah sakit, dengan bantuan keluarga, siapa saja bisa melakukan therapeutic exercise walking ini. Khususnya penderita PPOK hendaknya mulai melakukan therapeutic exercise walking dengan teratur untuk mendapatkan tingkat kualitas tidur yang lebih baik lagi daripada sebelumnya.

3. Penelitian selanjutnya

Hasil penelitian ini hendaknya digunakan sebagai bahan acuan bagi penelitian selanjutnya untuk mengetahui seberapa besar pengaruh therapeutic exercise walking terhadap kualitas tidur. Penelitian selanjutnya, sebaiknya memiliki bagian kelompok kontrol dan jumlah sampel yang lebih banyak agar hasilnya lebih representatif, tetapi tetap memperhatikan jumlah responden efektif untuk dilakukan therapeutic exercise walking.

\section{DAFTAR PUSTAKA}

Arikunto, S. (2014). Prosedur Penelitian. Jakarta: Rineka Cipta. 
GOLD. (2016). Global Strategy for The Diagnosis, Management, and Prevention of Chronic Obstructive Pulmonary Disease (Update 2016). Gold Initiative for Chronic Obstructive Lung Disease. Inc.

Khomarun, Nugroho, M.A.,

Wahyuni, E.S. (2014).

Pengaruh Aktivitas Fisik

Jalan Pagi Terhadap

Penurunan Tekanan Darah

Pada Lansia Dengan

Hipertensi Stadium I di

Posyandu Lansia Desa

Makamhaji. Jurnal Terpadu

Ilmu Kesehatan, Volume 3,

No 2, November 2014, hlm

106-214.

Notoatmodjo, S. (2012). Metodologi

Penelitian Kesehatan.

Jakarta: Rineka Cipta.

Nungtjik, A. K, dkk. (2010). Efikasi Pemberian Kombinasi

Inhalasi Salmeterol dan

Flutikason Propionat Melalui

Alat DIskus pada Penyakit

Paru Obstruktif Kronik.

Majalah Kedokteran

Indonesia.
Perhimpunan Dokter Paru Indonesia.

(2011). Penyakit Paru

Obstruktif Kronik (PPOK)

Pedoman Diagnosis \&

Penatalaksanaan di

Indonesia. PDPI.

Potter, P. A., \& Perry, A. G. (2006).

Buku Ajar Fundamental

Keperawatan. Jakarta: EGC.

Riset Kesehatan Dasar. (2013).

Badan Penelitian dan

Pengembangan Kesehatan

Kementerian Kesehatan RI

Tahun 2013. Riskesdas.

World Health Organization. (2004).

Prevention and Control of

Chronic Respiratory Diseases

at Country Level. Geneva, Switzerland. 